\title{
Synergistic Antioxidant Effects of Rosemary and $\alpha$-Tocopherol at Different Storage Temperatures and Its Application for Inhibiting Dried Sardine Meat Oxidation
}

\author{
Shun WADA* and Xin FANG \\ Department of Food Science and Technology, Tokyo University of Fisheries \\ (4-5-7 Konan, Minato-ku, Tokyo, $\mathbf{\top} 108)$
}

A mixture of $\alpha$-tocopherol and rosemary extract, as additives each at $0.035 \%$ (total $0.07 \%$ ), expressed very strong antioxidant activity in sardine oil stored at $30^{\circ} \mathrm{C}, 50^{\circ} \mathrm{C}$ and dried sardine meat at $5{ }^{\circ} \mathrm{C}$. In sardine oil, their combination not only inhibited the formation of hydroperoxides much more effectively than when present separately but the activity of tocopherol was retained for a longer period. In dried sardine meat, combined application caused the lowest PV, and (EPA+DHA)/16: 0 was higher. There was also lesser decomposition of triacylglycerol due to oxidation. Synergistic antioxidant effect was observed in sardine oil at $30^{\circ} \mathrm{C}$ and $50^{\circ} \mathrm{C}$, and in dried sardine meat at $5^{\circ} \mathrm{C}$. The antioxidant activity of rosemary extract was lost at of $90^{\circ} \mathrm{C}$, as was also the synergistic effect.

\section{Introduction}

Fish proteins and lipids are abundant sources of food for human beings. Fish oil characteristically contains large amounts of polyunsaturated fatty acids such as icosapentaenoic acid (EPA) and docosahexaenoic acid (DHA), the physiological functions of which have been the focal point of interest in recent studies. However, fish meat usually contains $70 \%$ water and thus easily spoils and deteriorates due to biological and chemical changes. The removal of water should reduce the cost of transportation and storage and increase product stability. But low water content would lead to considerable fish lipid oxidation. Studies on the relationship between water activity and oxidation indicate the oxidation of lipid to proceed quickly with decrease in water activity $^{1) \sim 3)}$. Control of lipid oxidation is very important to the utilization of dried fish meat. Tocopherol is presently used for inhibiting the oxidation of oil and oil-containing food ${ }^{4), 5)}$. The antioxidant capability

\footnotetext{
* To whom correspondence should be addressed
}

of tocopherol is limited and this compound may function as a prooxidant when present at high additive concentration ${ }^{6) \sim 8)}$. Consequently, new natural antioxidants and synergist of tocopherol have been sought. Ascorbic acid, phospholipids, some amino acids such as $\mathrm{L}$-histidine, $\mathrm{L}$-tryptophan, $\mathrm{L}^{-}$ methionine, L-lysine and several organic acids such as citric, malic and succinic have been found effective synergists for enhancing the antioxidant activity of tocopherol, even though any one of these compounds, when present alone, does not express antioxidant activity ${ }^{9) \sim 12)}$. As a natural antioxidant, the effectiveness of rosemary extract was recognized by Chang in $1977^{13)}$. He found this extract to impart unfavorable taste to products when present high additive concentration. The usefulness of $\alpha$-tocopherol and the rosemary extract diminishes with increase in concentration, but is augmented by their application in combination. Under these conditions, strong antioxidant activity may be expected due to their synergism.

In the previous study, discussion was 
made of the results of a combination of 0.05 $\%$ tocopherol and $0.02 \%$ rosemary extract. Stronger antioxidant effect than by $0.05 \%$ tocopherol and $0.02 \%$ rosemary alone was achieved. Synergistic effect was observed both in sardine oil and frozen-crushed fish meat ${ }^{14)}$. In this study, to more clearly demonstrate synergistic effect, each of these agents was used at $0.07 \%$ in all experiments. Tocopherol and the rosemary extract, applied separately each at $0.07 \%$ or as a mixture each at $0.035 \%$ (total $0.07 \%$ ), were examined for their synergistic antioxidant effect in sardine oil stored at $30^{\circ} \mathrm{C}, 50^{\circ} \mathrm{C}$ and $90^{\circ} \mathrm{C}$ and dried sardine meat at $5^{\circ} \mathrm{C}$.

\section{Materials and Method}

Fresh sardine (Sardinops melanosticta) were obtained from a fish market in Tokyo.

\subsection{Preparation of Sardine Oil Samples}

Sardine oil was extracted by the Bligh and Dyer method ${ }^{15)}$ following removal of bones and internal organs. Antioxidant addition to sardine oil was as follows : (1) control containing no antioxidants (Control), (2) mixture of antioxidants containing $0.035 \%$ (wt/wt) $\alpha$-tocopherol and 0.035 $\%$ (wt/wt) rosemary extract (Toc $+\mathrm{RM}),(3)$ $0.07 \%$ (wt/wt) $\alpha$-tocopherol (Toc), and (4) $0.07 \%$ (wt/wt) rosemary extract (RM). The rosemary was supplied by ASAMA KASEI (Tokyo, Japan) which was extracted by alcohol. Since the oxidation of fish oil at low temperature (such as $5^{\circ} \mathrm{C}$ ) requires considerable time, $10 \mathrm{~g}$ of sardine oil for each sample were well mixed with antioxidants, stored at $30^{\circ} \mathrm{C}, 50^{\circ} \mathrm{C}$ and $90^{\circ} \mathrm{C}$ respectively, in the dark in an open petri dish (diameter: $9.2 \mathrm{~cm}$, depth : $1.2 \mathrm{~cm}$ ), and stirred twice a day during storage.

\subsection{Preparation of dried sardine meat}

Fresh sardine meat without bones or internal organs was dried by freeze dryer (Freeze Dryer FDU-830, EYELA). Following the removal of original lipids, lipid content was adjusted to $20 \%$ (wt/wt) by the addition of fresh sardine oil. Antioxidant concentrations were the same as for the sardine oil system. On each experiment, $25 \mathrm{~g}$ of dried sardine meat was used. Following an- tioxidant addition, the mixture was divided into 5 subsamples. Fish meat easily deteriorates and microbes easily propagate at 30 ${ }^{\circ} \mathrm{C}$. Thus, to avoid the effects of biochemical and bacterial changes during storage, the samples were stored $5{ }^{\circ} \mathrm{C}$ in petri dishes in the dark and stirred twice a day.

\subsection{Assesment of lipid oxidation}

Peroxide value (PV) of each sample was determined as follows : Samples of $2 \sim 10$ mg were introduced into test tubes and accurately weighted. While under a stream of nitrogen, $1.0 \mathrm{~mL}$ of acetic acid : chloroform ( $3: 2$ ), and then $0.05 \mathrm{~mL}$ of potassium iodide (55\% wt/wt) were quickly added, followed by thorough mixing. The samples were left in the dark at room temperature for exactly $5 \mathrm{~min}$, followed by the addition of $3.0 \mathrm{~mL}$ of cadmium acetate aq $(0.5 \%$ wt/wt). The solution was mixed and centrifuged at $1,000 \times \mathrm{g}$ for $10 \mathrm{~min}$. Absorbance of the upper phase was determined at 353 $\mathrm{nm}$ against a blank containing the complete assay mixture minus the lipid. PV was calculated based on a molar extinction coefficient of $1.73 \times 10^{4} \mathrm{M}^{-116)}$.

Loss of long chain fatty acid as determined from ratio of $(\mathrm{EPA}+\mathrm{DHA}) / 16: 0$ served as the basis for assessing oxidation in sardine lipid extracted from dry sardine meat.

\subsection{Analysis of $\alpha$-Tocopherol}

Tocopherol analysis was conducted with a SHIMADZU 6 A high performance liquid chromatographic (HPLC) system (Shimadzu Corporation Kyoto, Japan). A nucleosil column $[50-5,250 \mathrm{~mm} \times 4.6 \mathrm{~mm}$ (i. d.), Gasukuro Kogyo Inc. Tokyo, Japan] was used for separation of $\alpha$-tocopherol. The mobile phase was hexane : tetrahydrofuran : methanol $(92.5: 25: 2.5, \mathrm{vol} / \mathrm{vol} / \mathrm{vol})$ pumped at a flow rate of $1 \mathrm{~mL} / \mathrm{min}$. $\alpha$-Tocopherol was detected by a fluorescent detector using excitation and emission wavelengths of $298 \mathrm{~nm}$ and $325 \mathrm{~nm}$, respectively.

Sardine lipids in the dry meat were extracted by the Bligh-Dyer method.

\subsection{Lipid Class}

The lipid composition of dry sardine meat was determined by thin layer chromatogra- 
phy (TLC) using a Kieselgel 60 plate $(0.25$ mm thick, E. Merck Japan, Tokyo, Japan). The plate was developed with petroleum ether : diethyl ether : acetic acid (80:20:1 $\mathrm{vol} / \mathrm{vol} / \mathrm{vol}$ ) and then sprayed with saturated potassium dichromate in $75 \%$ ( $\mathrm{vol} / \mathrm{vol}$ ) sulfuric acid, and heated at $130^{\circ} \mathrm{C}$ for $5 \mathrm{~min}$. The charred zones were analyzed densitometrically using a SHIMADZU high speed TLC scanner (CS-9000) (Shimadzu Corporation Kyoto, Japan).

\subsection{Fatty Acid Composition}

Fresh sardine was purchased from central fish market in Tokyo. Lipids of sardine meat were converted to fatty acid methyl esters in a mixture of benzene and boron trifluoride methanol complex solution at $85^{\circ} \mathrm{C}$ for $30 \mathrm{~min}$. The esters were analyzed by gas liquid chromatography (GLC) (GC-7 A, Shimadzu Corporation Kyoto, Japan) on a glass column $(2 \mathrm{~m} \times 3 \mathrm{~mm}$ i.d. $)$ packed with Unisole 3000 (Gasukuro Kogyo Inc. Tokyo, Japan). The chromatographic conditions were an oven temperature fo $215^{\circ} \mathrm{C}$, injection port temperature, $250^{\circ} \mathrm{C}$, and flame ionization detector temperature, $250^{\circ} \mathrm{C}$. Nitrogen was used as the carrier gas at a flow rate of $50 \mathrm{~mL} / \mathrm{min}$.

\section{Results and Discussion}

3.1 Synergistic antioxidant effects on sardine oil during storage at $30^{\circ} \mathrm{C}$

Fig. -1 shows changes in $\mathrm{PV}$ of sardine oil during storage at $30^{\circ} \mathrm{C}$. PV of the control increased to over $100 \mathrm{meq} / \mathrm{kg}$ after $10 \mathrm{~d}$, and rose rapidly to $1150 \mathrm{meq} / \mathrm{kg}$ after storage for $15 \mathrm{~d}$. The induction period of the control sample was $10 \mathrm{~d}$. For the tocopherol-treated sample, PV increased gradually and reached $100 \mathrm{meq} / \mathrm{kg}$ after $20 \mathrm{~d}$ and about $300 \mathrm{meq} / \mathrm{kg}$ with storage for $35 \mathrm{~d}$. Rapid increase in PV in the tocopherol-treated sample was observed after storage of $39 \mathrm{~d}$. Compared with tocopherol treatment, PV of the rosemarytreated sample reached about $100 \mathrm{meq} / \mathrm{kg}$ after storage for $35 \mathrm{~d}$, and increased to 800 $\mathrm{meq} / \mathrm{kg}$ rapidly at $39 \mathrm{~d}$. The induction periods for the tocopherol or rosemary treated samples were essentially the same, but PV of the rosemary-treated sample was

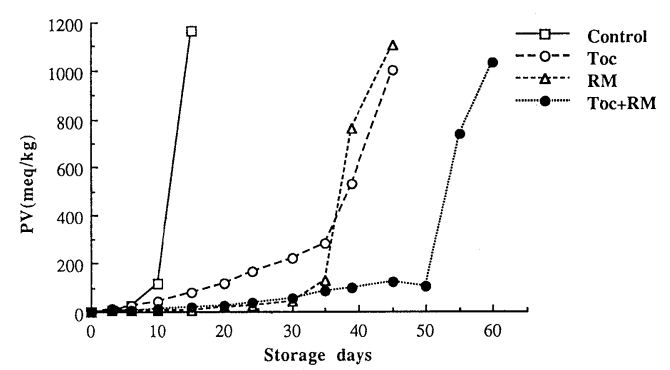

Fig. -1 Changes in PV of sardine oil during storage at $30^{\circ} \mathrm{C}$.

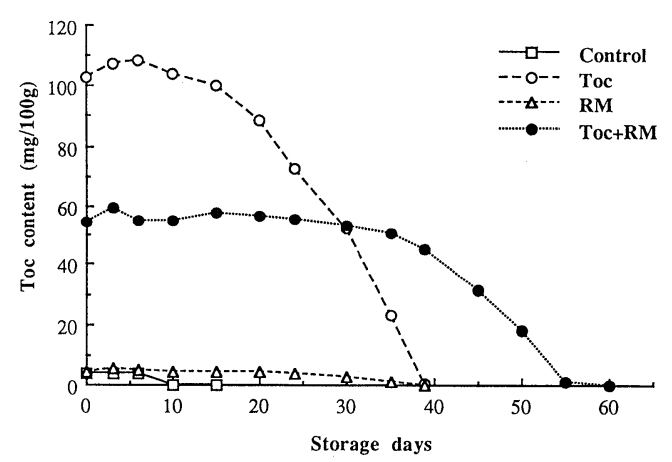

Fig.-2 Changes in Toc content of sardine oil during storage at $30^{\circ} \mathrm{C}$.

significantly lower than that of tocopheroltreated sample during $35 \mathrm{~d}$ of storage. The antioxidant effect of rosemary thus appears much stronger than tocopherol, since the formation of hydroperoxides was very effectively inhibited. Combined treatment showed the strongest antioxidant activity. $\mathrm{PV}$ was maintained below $100 \mathrm{meq} / \mathrm{kg}$ for $50 \mathrm{~d}$ but then rapidly increased during next $5 \mathrm{~d}$. The induction period of combined treatment was $50 \mathrm{~d}$, this being $15 \mathrm{~d}$ longer than for either tocopheroxy or rosemary separately, even though the total concentration of additives for each treatment was the same. Synergistic effect was apparent during storage at $30^{\circ} \mathrm{C}$.

Fig. -2 shows changes in the tocopherol content of sardine oil stored at $30^{\circ} \mathrm{C}$. Sardine oil contained about $5 \mathrm{mg} / 100 \mathrm{~g}$ of $\alpha-$ tocopherol, which was exhausted after storage for $10 \mathrm{~d}$. At the start of storage, tocopherol content of rosemary-treated sample was basically the same as that of the control 
sample, indicating the rosemary extract to contain no tocopherol. The tocopherol content of the rosemary-treated sample remained essentially unchanged during the first $20 \mathrm{~d}$ of storage, declined gradually up to $30 \mathrm{~d}$ and ceased to be undetectable after $40 \mathrm{~d}$. The lifetime of tocopherol in the rosemary-treated sample was $30 \mathrm{~d}$ longer than that of the control, though tocopherol content in both at the beginning of storage was basically the same. The function of tocopherol was clearly prolonged by rosemary. For the tocopherol-treated sample, tocopherol content decreased slightly during first $15 \mathrm{~d}$ of storage, but quite rapidly decreased after $20 \mathrm{~d}$; it was no longer present after $39 \mathrm{~d}$. In contrast, tocopherol in combined treatment showed little change during $30 \mathrm{~d}$ storage and was oxidized almost completely at $60 \mathrm{~d}$. The lifetime of tocopherol in combined treatment was $20 \mathrm{~d}$ longer than that of the tocopherol-treated sample due to the synergist effect of rosemary, even though the former had only half the tocopherol content of the latter.

\subsection{Synergistic antioxidant effect on sar-} dine oil during storage at $50^{\circ} \mathrm{C}$

Synergistic effect was examined at temperature higher than $30^{\circ} \mathrm{C}$. Fig. -3 shows changes in $\mathrm{PV}$ of sardine oil during storage at $50^{\circ} \mathrm{C}$. PV of the control sample increased rapidly after storage for $12 \mathrm{~d}$. Compared to the tocopherol-treated sample, although the rosemary-treated sample appeared most effective for inhibiting the formation of hydroperoxides during first $15 \mathrm{~d}$ of storage, sharp increase in PV was observed at $20 \mathrm{~d}$, and the induction period of the rosemarytreated sample was shorter than that of the tocopherol-treated sample. In contrast to storage at $30^{\circ} \mathrm{C}$, antioxidant acitivity of the rosemary extract appeared less effective for preventing oxidation than tocopherol at 50 ${ }^{\circ} \mathrm{C}$. However, the combined treatment sample still expressed the strongest antioxidant effect of all samples. Its induction period was $4 \mathrm{~d}$ and $17 \mathrm{~d}$ longer than that of the tocopherol or rosemary treated sample, respectively. The synergistic effect was apparent during storage at $50^{\circ} \mathrm{C}$.

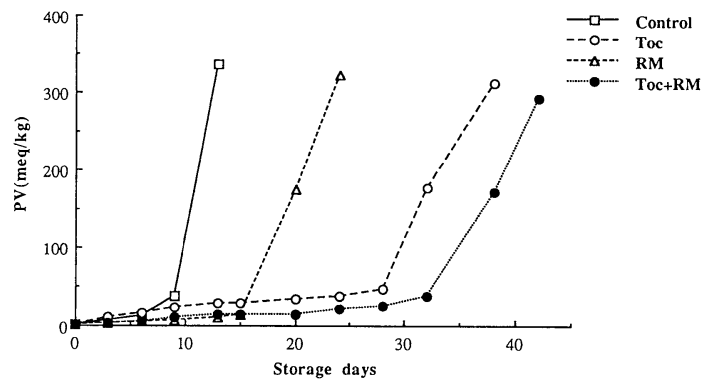

Fig. -3 Changes in PV of sardine oil during storage at $50^{\circ} \mathrm{C}$.

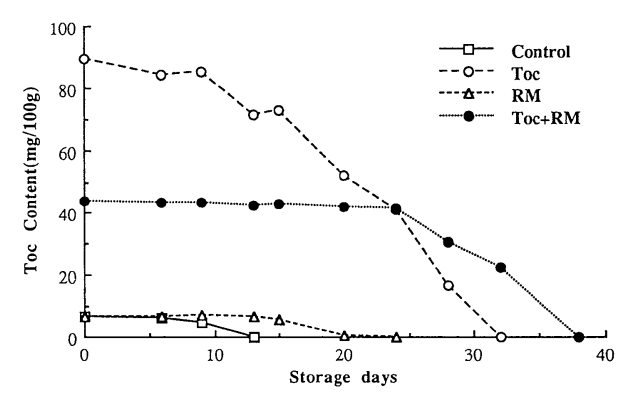

Fig. -4 Changes in Toc content of sardine oil during storage at $50^{\circ} \mathrm{C}$.

Changes in tocopherol content during storage at $50^{\circ} \mathrm{C}$ are shown in Fig. - 4. As also noted at $30^{\circ} \mathrm{C}$, the lifetime of tocopherol in the rosemary-treated sample was $8 \mathrm{~d}$ longer than that of the control. On comparing the combined-treated sample with the tocopherol-treated sample, the lifespan of tocopherol in the combined-treated sample was expressed $6 \mathrm{~d}$ longer than in the sample of tocopherol alone, even though the former contained only half the tocopherol content of the latter. Tocopherol in rosemary alone and combined-treated samples is thus regenerated by rosemary when oxidized to tocopherol during storage. In storage at $50^{\circ} \mathrm{C}$, antioxidant activity of the rosemary extract clearly decreases but the synergistic antioxidant effect persists, as indicated by the results of PV and tocopherol content.

3.3 Synergistic antioxidant effect in sardine oil during storage at $90^{\circ} \mathrm{C}$

Changes in $\mathrm{PV}$ and tocopherol content during storage at $90^{\circ} \mathrm{C}$ are shown in Fig. -5 and Fig.-6. High storage temperature caused rapid oxidation compared to storage 


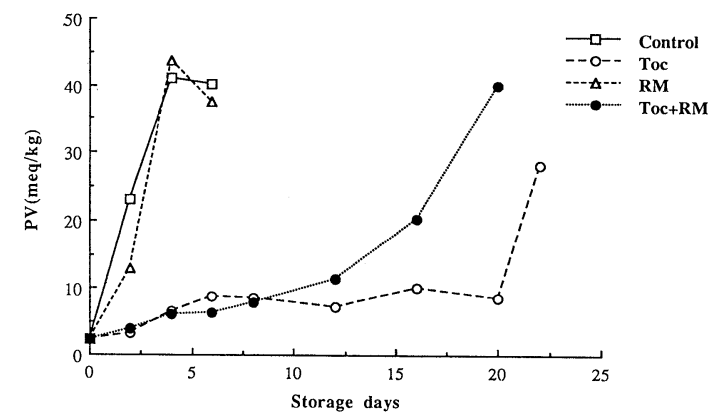

Fig. -5 Changes in PV of sardine oil during storage at $90^{\circ} \mathrm{C}$.

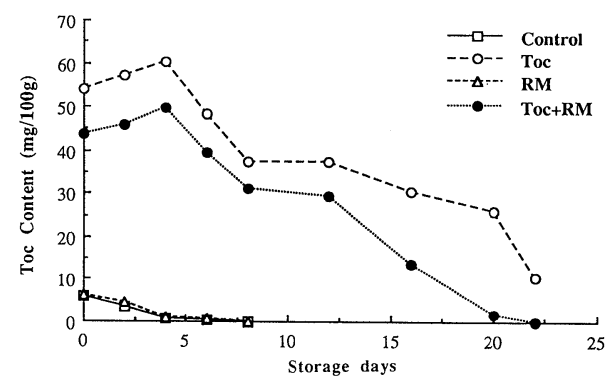

Fig.-6 Changes in Toc content of sardine oil during storage at $90^{\circ} \mathrm{C}$.

at $30^{\circ} \mathrm{C}$ and $50^{\circ} \mathrm{C}$. For the control and rosemary samples, PV rapidly increased after storage for $2 \mathrm{~d}$. The rosemary extract showed no antioxidant activity during storage at $90^{\circ} \mathrm{C}$, as evident from the finding that there was no significant difference in their induction periods. Neither was there synergistic effect, in that PV with combined treatment increased much early compared to the tocopherol-treated sample. The changes in tocopherol content were consistent with those in $\mathrm{PV}$; decrease in tocopherol content in the control and rosemary treated samples were similar, and tocopherol in both eventually became undetectable on the same day of storage. Tocopherol content of combined sample was eliminated much quickly than that in the tocopherol treated sample.

It is evident from the above that the antioxidant activity of the rosemary extract is easily affected by storage temperature. At $30^{\circ} \mathrm{C}$, it showed stronger antioxidant effect than tocopherol, it was less than that of tocopherol at $50^{\circ} \mathrm{C}$ and was completely absent at storage of $90^{\circ} \mathrm{C}$. The synergistic antioxidant effect was also lost.

In comparison of changes in $\mathrm{PV}$ with tocopherol content at $30^{\circ} \mathrm{C}, 50^{\circ} \mathrm{C}$ and $90^{\circ} \mathrm{C}$, tocopherol would appear to function as an antioxidant scavenging free radicals and singlet oxygen to inhibit hydroperoxides formation. When scavenger has completely reacted, lipid oxidation advances quickly.

In consideration of the antioxidant activity of rosemary and synergistic effect at different storage temperature, the rosemary extract would appear to function as a synergist to regenerate tocopherol from tocopheroxy radicals by providing hydrogen atoms or preventing the inactivation of tocopherol by combining with substances such as metal ions. Explanation for this is that tocopherol in rosemary treated sample and combined-treated sample undergoes little change during the initial period of storage and thus its lifespan is prolonged. Decrease in tocopherol advanced suddenly toward the end of storage probably since the rosemary extract completely reacted with oxidized tocopherol. At $90^{\circ} \mathrm{C}$, the function of rosemary extract was lost due to high temperature, thus eliminating the synergistic effect. However, changes in rosemary content during storage were difficult to determine owing to the presence of the secondary products of lipid oxidation.

3.4 Synergistic antioxidant effect in dried sardine meat during storage at $5^{\circ} \mathrm{C}$

Fig. -7 shows changes in PV of dry sardine meat during storage at $5^{\circ} \mathrm{C}$. The control sample consistently showed the highest

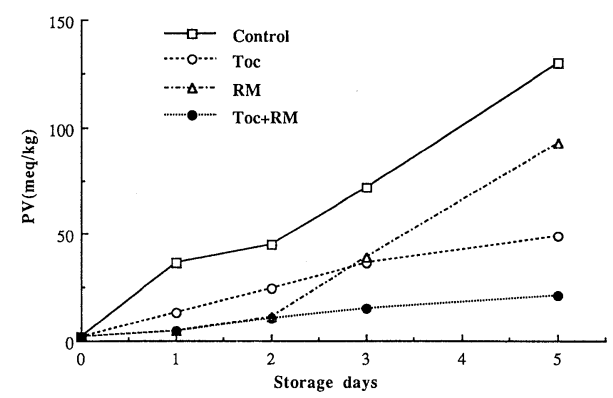

Fig. -7 Changes in $\mathrm{PV}$ of dried sardine meat during storage at $5^{\circ} \mathrm{C}$. 


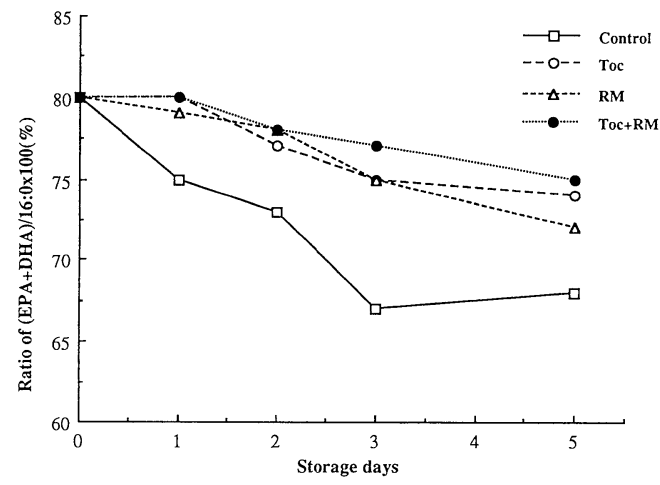

Fig. -8 Changes in the ratio of $(\mathrm{EPA}+\mathrm{DHA}) / 16$ : $0 \times 100 \%$ of dried sardine meat during storage at $5^{\circ} \mathrm{C}$.

PV for any treatment throughout $5 \mathrm{~d}$ of storage. PV exceeded $130 \mathrm{meq} / \mathrm{kg}$ after $5 \mathrm{~d}$. Lipid oxidation in dry sardine meat thus appears much more extensive than in sardine oil even at $5^{\circ} \mathrm{C}$. Compared with the tocopherol-treated sample, PV of the rosemary-treated sample was less at $2 \mathrm{~d}$, essentially the same at $3 \mathrm{~d}$ and increased much more quickly than the former at $5 \mathrm{~d}$. Oxidation in combined treatment sample was effectively inhibited by the synergistic effect and PV remained lowest for any treatment, particulary at 3 and $5 \mathrm{~d}$.

Fish lipid characteristically contains large quantities of polyunsaturated fatty acids such as EPA and DHA. EPA and DHA are very easily oxidized due to their high unsaturation and thus the ratio of $(\mathrm{EPA}+\mathrm{DHA}) / 16$ : 0 can be used to follow the oxidative deterioration of polyunsaturated fatty acids ${ }^{17)}$. (EPA+DHA)/16:0 in the control sample quickly decreased and was lowest for all treatments throughout $5 \mathrm{~d}$ of storage, as shown in Fig.-8. This agree well with the results obtained for PV. Combined treatment consistently caused higher $(\mathrm{EPA}+\mathrm{DHA}) / 16: 0$ than other treatments, indicating the oxidation of polyunsaturated fatty acid to be inhibited by the synergistic effects of two antioxidants.

Changes in lipid composition were also investigated. No free fatty acid fraction could be found, thus showing no triacylglycerol (TG) hydrolysis to occur for any treatment throughout storage. The low water content

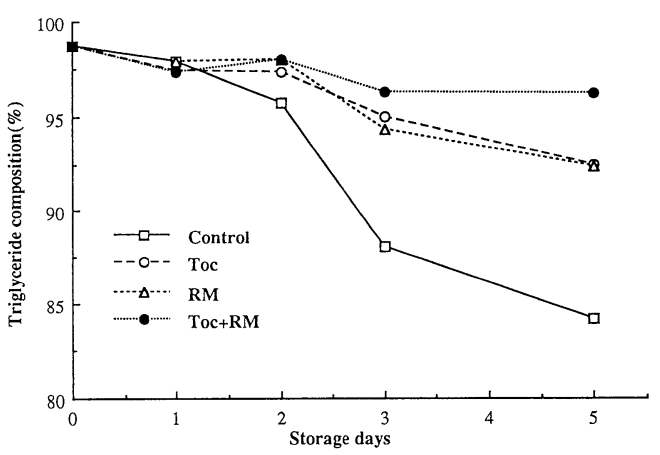

Fig. -9 Changes in triacylglycerol composition of dried sardine meat during storage at $5^{\circ} \mathrm{C}$.

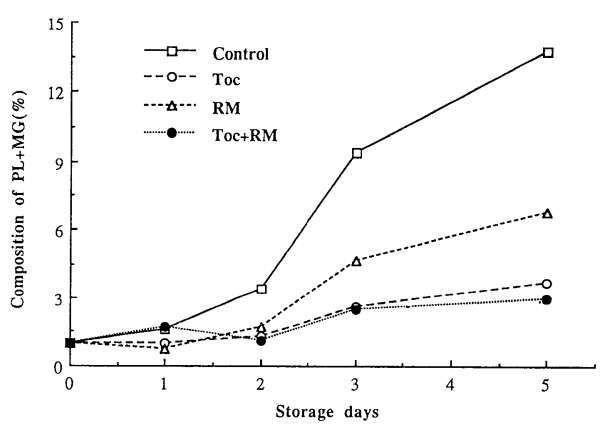

Fig. -10 Changes in PL+MG composition of dried sardine meat during storage at $5^{\circ} \mathrm{C}$.

in the system and inactivation of hydrolase during drying may have been the reasons for this. However, as shown in Fig. -9 , decline in TG composition persisted, possibly since the decomposition of $\mathrm{TG}$ was not caused by hydrolysis, but by oxidation. TG in the control sample decreased $15 \%$ of its original value after storage for $5 \mathrm{~d}$. In the tocopherol or rosemary treated sample, it declined about $5 \%$ after $5 \mathrm{~d}$. The combined-treated sample had the highest TG composition, particulary at 3 and $5 \mathrm{~d}$ of storage.

Increase in phospholipid and monoacylglycerol $(\mathrm{PL}+\mathrm{MG})$ composition is shown in Fig. -10 . Changes in PL $+M G$ composition accompanied those in $\mathrm{TG}$, since increase in $\mathrm{PL}+\mathrm{MG}$ of the combined-treated sample was less than in other treatments.

\section{Conclusions}

It follows from the present results that tocopherol and the rosemary extract in com- 
bination exert stronger antioxidant effect than when present separately in sardine oil and dried sardine meat. For sardine oil, antioxidant capability of tocopherol in combined treatment is significantly maintained with increase in its lifespan. For dried sardine meat, combination of two antioxidants result not only in inhibiting most effectively the formation of hydroperoxides, but cause the lowest oxidative rate of polyunsaturated fatty acid and lowest decomposition of triacylglycerol causing by oxidation. The synergistic antioxidant effect of tocopherol with the rosemary extract was confirmed in the sardine oil and dry sardine meat samples. This effect should find important applications in the production of fish oil and other products in the food industry.

(Received July, 13, 1993)

\section{Reference}

1) H.F. Martin, J. Sci. Food Agric., 9, 817 (1958).

2) K.A. Munday, M.L. Edwards, and G.A. Kerkut, J. Sci. Agric., 13, 455 (1962).

3) F. Martinez and T.P. Labuza, J. Food Sci., 33, 241 (1968).

4) L.R. Dugan and H.R. Kraybill, J. Am. Oil Chem. Soc., 33, 527 (1956).

5) M. Loury, C. Bloch, and F. Francois, Rev. Corps Cras., 13, 747 (1966).

6) W.M. Cort, J. Am. Oil Chem. Soc., 51, 321 (1974).

7) J. Cillard and P. Cillard, J. Am. Oil Chem. Soc., 63, 1165 (1986).

8) S.R. Husain, J. Cillard, and P. Cillard, J. Am. Oil Chem. Soc., 64, 109 (1987).

9) O.S. Yi, D. Han, and H. K. Shin, J. Am. Oil Chem. Soc., 68, 881 (1991).

10) D.H. Hildebrand, J. Terao, and M. Kito, $J$. Am. Oil Chem. Soc., 61, 552 (1984).
11) M. Aoyama, T. Maruyama, H. Kanematsu, I. Niiya, M. Tsukamoto, S. Tokairin, and T. Matsumoto, J. Jpn. Oil Chem. Soc., 36, 662 (1987).

12) H.W. Lemon, R.M. Knapp, and A.H. Allman, Can. J. Res., 28, 453 (1950).

13) S.S. Chang, B.O. Matijasevic, and O.A.I. Hsieh, J. Food Sci., 42, 1102 (1977).

14) S. Wada and X. Fang, J. of Food Process. \& Preservation, 16, 263 (1992).

15) E.G. Bligh and W.J. Dyer, Can. J. Biochem. Physiol., 37, 911 (1959).

16) S. Fleisher and L. Pucker, "Microsomal Lipid Peroxidation", Academic Press, New York (1978) p. 302.

17) T. Shono and M. Toyomizu, Bull. of Jpn. Soc. Fish., 37, 912 (1971).

異なる貯蔵温度でのローズマリー及び $\alpha-卜$ コフェロールの酸化防止相乗作用と乾燥イワ シ肉の酸化防止への応用

$$
\begin{gathered}
\text { 和田 俊・房 昕 } \\
\text { 東京水産大学食品生産学科 (テ108 東京都港区港南 4-5-7) } \\
\text { ローズマリー }(\mathrm{RM}) \text { と } \alpha \text {-トコフェロール (Toc) の }
\end{gathered}
$$
混合添加区 $(0.035 \%+0.035 \%)$ による酸化防止相乗効 果についてイワシ油及びイワシ凍結乾燥肉を用いて検討 した。RM あるいは Toc の単独添加区 $(0.07 \%)$ に比 べ, 混合添加区の強い酸化防止力はイワシ油では $30^{\circ} \mathrm{C}$,

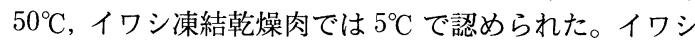
油では, その相乗効果は貯蔵中における過酸化脂質の形 成をよく抑制するだけではなく, Toc の酸化防止活性を 持続し, 残存期間を延長した。イワシ凍結乾燥肉では, 混合添加区の過酸化物価が一番低く, さらに, $(\mathrm{EPA}+$ DHA)/16:0 の比は高く, 高度不飽和脂肪酸の酸化を 有効に抑制した。イワシ凍結乾燥肉では混合添加区の卜 リアシルグリセロール (TG) の組成比は高く, 酸化に よる TG の分解もよく抑えた。しかし，イワシ油 $90^{\circ} \mathrm{C}$ では, RM の酸化防止力及び Toc との相乗効果はとも に失活した。

（連絡者：和田 俊） 